Goldschmidt 2021 Abstract

https://doi.org/10.7185/gold2021.7183

\section{REFERTILIZED CONTINENTAL LITHOSPHERE BENEATH CATALÃO, ALTO PARANAÍBA IGNEOUS PROVINCE, EVIDENCED BY \\ CLINOPYROXENES FROM METASOMATIZED MANTLE PERIDOTITES}

\author{
RODRIGO ANTONIO DE FREITAS RODRIGUES ${ }^{1}$,
} FERNANDA GERVASONI ${ }^{2}$, TIAGO JALOWITZKI ${ }^{3}$, YANNICK BUSSWEILER ${ }^{4}$, JASPER BERNDT ${ }^{4}$, STEPHAN KLEMME $^{5}$, NILSON FRANCISQUINI BOTELHO ${ }^{6}$, BRUNNO ABILIO CIRIACO ${ }^{6}$ AND ÍTALO LOPES DE OLIVEIRA $^{6}$

${ }^{1}$ University of Brasília

${ }^{2}$ Universidade Federal de Goiás (UFG)

${ }^{3}$ Universidade de Brasília (UnB)

${ }^{4}$ University of Münster

${ }^{5}$ Universität Münster

${ }^{6}$ Universidade de Brasília

Presenting Author: rodrigues.rafr@gmail.com

Volcanic rocks with kimberlite affinity located in the Alto Paranaíba Igneous Province (APIP), Catalão region, Central Brazil, host a suite of mantle-derived xenoliths that provide valuable insights into the nature and evolution of the continental lithosphere. These peridotites vary from spinel-lherzolites to clinopyroxene-bearing harzburgite, and phlogopite-garnetwehrlites. In-situ major and trace element analyses of clinopyroxenes reveal a broad range of temperature $(\mathrm{T})$ and pressure $(\mathrm{P})$ conditions, as well as distinct enrichment processes. Wehrlites $\left(958-1043{ }^{\circ} \mathrm{C}\right.$; 4.2-5.3 GPa) and harzburgite (905-990 ${ }^{\circ} \mathrm{C}$; $5.0 \mathrm{GPa}$ ) were formed at higher T-P than spinel-lherzolites (730-888 ${ }^{\circ} \mathrm{C}$; $\left.1.6-1.8 \mathrm{GPa}\right)$. Clinopyroxenes in wehrlites display $\mathrm{Mg} \#$ between 0.91 and 0.92 , high $\mathrm{Ca} / \mathrm{Al}$ (13.34-20.20) and $\mathrm{La} / \mathrm{Yb}_{\mathrm{N}}(56.79-117.88)$ ratios, and high $\mathrm{Cr}$ contents (1.38-2.18 wt.\%) coupled with low Ti/Eu ratios (481-1069). They also have high $\mathrm{Sr}(187-531 \mathrm{ppm})$ and $\mathrm{Ba}(2-85 \mathrm{ppm})$ contents and high $\mathrm{Nb} / \mathrm{Ta}$ ratios (15.71-22.61). Clinopyroxenes in harzburgite have $\mathrm{Mg} \#$ between 0.93 and 0.95 , high $\mathrm{Ca} / \mathrm{Al}$ (12.55-17.87) and $\mathrm{La} / \mathrm{Yb}_{\mathrm{N}}$ (7.58-10.51) ratios, high $\mathrm{Cr}$ contents (1.15-1.87 wt.\%) and intermediate $\mathrm{Ti} / \mathrm{Eu}$ ratios (2583-3252). $\mathrm{Sr}$ (209-325 ppm) and $\mathrm{Ba}(40.60-73.10 \mathrm{ppm})$ are comparatively high with $\mathrm{Nb} / \mathrm{Ta}$ reaching the highest values (127.54-205.58) among all samples. Conversely, clinopyroxenes from the spinel-lherzolites show wide range of $\mathrm{Mg} \#(0.90-0.94,0.93$ on average) with low $\mathrm{Ca} / \mathrm{Al}$ (2.90-4.09) and $\mathrm{La} / \mathrm{Yb}_{\mathrm{N}}(0.001-0.073)$ ratios, low $\mathrm{Cr}$ contents (0.49-0.99 wt.\%), and the highest $\mathrm{Ti} / \mathrm{Eu}$ values (4410-6904) when compared to wehrlites and harzburgite. $\mathrm{Sr}$ (6.26-59.20 ppm), $\mathrm{Ba}$ (0.01-2.57 ppm) and $\mathrm{Nb}$ (0.01-0.35 ppm) concentrations are low and Ta contents are below detection limits. The geochemical signatures of clinopyroxenes from wehrlites and harzburgite suggest that they were formed by reactions between a residual peridotite and a metasomatic melt. The formation of wehrlites may indicate an intense metasomatism in the deep lithosphere $(>140 \mathrm{~km})$ caused by melt percolation of carbonatite affinity. The LREE enrichment, high $\mathrm{Ca} / \mathrm{Al}$, low to moderate $\mathrm{Ti} / \mathrm{Eu}$, high $\mathrm{Sr}$ and $\mathrm{Nb}$ coupled with high $\mathrm{Nb} / \mathrm{Ta}$ ratios support this hypothesis. Moreover, clinopyroxenes in the spinel-lherzolites present limited interaction with the metasomatic agent and their REE patterns are typical of melt extraction processes, which suggests that the refertilization was restricted to the deeper parts of the APIP continental lithosphere. 